\title{
Impacts of Land Use Changes on Selected Soil Physical and Chemical Characteristics under Pineapple Cropping Systems in Matara District, the Low Country Wet Zone of Sri Lanka
}

\author{
B.C. Walpola* , A.P.I. Mendis
}

Department of Soil Science, Faculty of Agriculture, University of Ruhuna, Mapalana, Kamburupitiya, Sri Lanka

\section{Correspondence:}

*bcwalpola@soil.ruh.ac.lk

(D) https://orcid.org/0000-0002-7081-0215

\begin{abstract}
The present paper investigated the impacts of land use change on physical and chemical characteristics of soil. A land, originally inhabited by native secondary forest, later converted to pineapple cultivation was selected for collection of representative soil samples from the $0-15 \mathrm{~cm}$ depth. A closely forest land was used as the reference. Soil texture, bulk density, aggregate stability, $\mathrm{pH}$, total nitrogen, available soil $\mathrm{P}$, exchangeable $\mathrm{K}$ and organic matter (OM) content were determined following standard methods. According to the results, significant variations in $\mathrm{OM}$, soil $\mathrm{pH}$, aggregate stability and available $\mathrm{P}$ were observed among forest and cultivated lands. The distribution of particle size revealed a decrease in larger particle size and an increase in smaller particle size following the conversion of natural forest to other land cover. Land use changes from forest to pineapple cultivation resulted in decreased aggregate stability, soil $\mathrm{pH}$ and organic matter content. The highest $\left(17.3 \mathrm{mg} \mathrm{kg}^{-1}\right)$ mean available $\mathrm{P}$ was recorded in the old pineapple land followed by forest land $\left(15.0 \mathrm{mg} \mathrm{kg}^{-1}\right)$ whilst the lowest in the new pineapple land (12.4 $\mathrm{mg} \mathrm{kg}^{-1}$ ). However the values of bulk density, total nitrogen content and exchangeable $\mathrm{K}$ content of forest and cultivated lands were not significantly different $(p \leq 0.05)$. Based on the results, it can be concluded that regular monitoring of soil properties is essential to maintain soil health, enhance agricultural productivity and sustain agro-ecosystems
\end{abstract}

Keywords: Forest land, land use systems, Soil physical and chemical properties 


\section{Introduction}

Soil is considered to be a key factor that determines crop productivity. As the characteristics of soil could vary with the type and origin of soil, it is important to distinguish soil as a substance on which plants are grown. The quality of native soil used in agriculture may change with time (Gu et al. 2011; Keith et al. 2012; Santorufo et al. 2012). Deforestation, cultivation, and introduction of pastures, etc., could result in changing soil's biological, physical, and chemical properties. Land use pattern and natural processes which influence natural resources including the soil properties are known to be the key drivers of environmental change. A considerable extent of productive lands is reported to be degraded due to poor management of land, which is a major threat to rural livelihood in many developing countries (Braimoh and Vlek 2008).

Natural forestlands and grasslands have been converted into arable lands in order to meet the increasing demand for food and other plant-based products (Abad et al. 2014). As revealed by many studies, intensive land use causes soil erosion (Wang et al. 2012; Wijitkosum 2012a;
Wijitkosum 2012b), soil quality, and soil degradation (Biro et al. 2013; Karltun et al. 2013; Ubuoh et al. 2013). Altering the forest ecosystem could have negative impacts on the organic inputs that cause a reduction in soil fertility (MuñozRojas et al. 2015; Saha and Kukal 2015), increased soil erosion (Biro et al. 2013), and finally accelerated the rate of soil degradation (Barua and Haque 2013). Many research studies have been conducted on land use/land cover changes and its impacts on soil degradation (Adugna and Abegaz 2016; Wijitkosum 2016) over the last decades. A study conducted by Wanniarachhi and Shyamalee (2005) to evaluate indicators to assess dynamic soil quality of agricultural lands, in Matara district recorded land management had a significant overall effect on the dynamic soil quality.

Furthermore, it was observed that bulk density and soil organic matter were robust indicators for evaluating soil quality of agricultural lands. Besides, they showed that plant nutrient levels, such as nitrogen, phosphorus, and potassium are not ideal indicators for evaluating soil chemical quality of agricultural lands as 
the levels can mask inferior quality by the application of fertilizers.

Plant cover is considered as the key indicator of soil degradation as it protects the soil against erosion by reducing water runoff (Kröpfl et al. 2013). However, land use changes result in species replacement and biotic homogenization or differentiation. Biro et al. (2013) observed that the conversion of natural ecosystems to agricultural systems can substantially affect severe soil degradation due to reducing the composition of plant species (mono-cropping), lack of crop rotation, inappropriate methods of soil preparation, and management. Adugna and Abegaz (2016) reported a lower organic matter, total nitrogen, cation exchange capacity, and $\mathrm{pH}$ in cultivated land compared to forestland and grazing land. Saha and Kukal (2015) observed a higher bulk density, lower macro-porosity and water retention in cultivated lands compared to forestlands and grasslands. This indicated a rapid physical, chemical and biological deterioration of soil and subsequent decline of agricultural productivity.

Therefore, reliable information on the effect of land use changes on soil physical and chemical properties is essential in order to recommend optimal and sustainable utilization of land resources. The purpose of this study was to quantify the effect of land use changes on selected soil physical and chemical properties.

\section{Methodology}

\section{Study area}

As classified by Punyawardena et al. (2003), the land selected for the study is located in agro-ecological region WL2 (low country wet zone) where the soil is Red Yellow Podzolic and is classified as Hapludults based on the USDA soil taxonomy (Mapa et al. 1999). The climate of the area is tropical monsoonal (Punyawardena 2003), with a warm wet period (April to June) and a relatively dry period (January to March). The area receives an annual rainfall of around 2500 $\mathrm{mm}$. The rainfall distribution is bi-model. The annual mean air temperature of the area is $22-30^{\circ} \mathrm{C}$ and the relative humidity is about $80 \%$.

The sampling location was in Ruhunugama, Kamburupitiya, in Matara district, Sri Lanka. A forestland and two cultivated lands (old and new growing 
lands) were identified as three major land use categories. According to the land use history, the selected site was reported to be a forest land until 1989. Since then, certain parts of the land have been converted to monoculture farming with pineapple (Ananas comosus), while the rest is remaining as forest. The cultivated area has suffered from continuous deforestation, mono-cropping, heavy usage of agrochemicals, and other agronomic practices.

\section{Soil sampling}

Soil samples were drawn from randomly selected sampling points after removing the surface litter. They were drawn from 0-15 cm depth (the average plough layer) using an auger. Samples were then mixed thoroughly in order to make a composite sample, air-dried, ground, and passed through a $2 \mathrm{~mm}$ sieve prior to laboratory analysis.

\section{Soil analysis}

Undisturbed core sampler method was used in determining soil bulk density. Aggregate stability was determined using a method as described by Kemper and Chepil (1965). Hydrometer method (Gee and Or 2002) was used in determining soil texture, where the soil was dispersed with sodium hexametaphosphate before taking the readings. Soil $\mathrm{pH}$ was measured using (1:2.5 soil: water) $\mathrm{pH}$ meter (HI 98127 HANNA). Walkley and Black method (Nelson and Sommer 1996) was used in calculating organic carbon (OC) content and thereby determined the organic matter $(\mathrm{OM})$ content using the formula $(\mathrm{OM} \%=1.721 \times \mathrm{OC})$. Exchangeable $\mathrm{K}^{+}$was extracted by ammonium acetate ( $\left.\mathrm{NH}_{4} \mathrm{OAC}\right)$ and determined using a flame photometer (Helmke and Sparks 1996). Micro-kjeldhal method (Bremner and Mulvaney 1982) was usedin determining the total nitrogen. Available soil phosphorous was extracted according to borax method (Dick and Tabatabai, 1977) and determined using a spectrophotometer (UV-VIS 160 Shimadzu).

\section{Statistical analysis}

Data generated were subjected to analysis of variance (ANOVA) using SAS software (SAS Institute 1988). Duncan's New Multiple Range Test (DNMRT) was applied to test the significance of treatment means 
at $p \leq 0.05$. Values were given as means \pm SD for triplicate samples.

\section{Results and Discussion}

\section{Bulk density}

As revealed by the results, no significant difference in the bulk density of the natural forest and two pineapple lands were observed (Fig. 1). Bulk density is considered to be a key physical parameter of a soil that determines the nutrient storage, retention of moisture, and movement of gas in the soil (Wang et al. 2010). As reported by Nascente et al. (2015), the bulk density of a soil is strongly correlated with organic matter and organic carbon content. We observed significant differences in soil organic matter content between forest land and pineapple lands while, no such differences were observed in bulk density of respective lands. According to Erdel (2012), bulk density is inversely correlated with the organic matter content which is also contentious with the present results.
Generally, lower bulk density values are reported when the soil contains higher proportions of clay. However, we have observed significantly higher clay contents in cultivated lands compared to natural forests though their bulk density values were not significantly different.

Furthermore, the effect of compaction due to the use of machinery and human traffic through the forest clearing, and agricultural practices such as ploughing, weed control, and harvesting on the bulk density might be negligible in the present study though such practices could result differences in bulk density (Biro et al. 2013). Celik (2005) also reported that deforestation and subsequent tillage practices could result in increased bulk density in surface soil. However, there might be some differences in soil bulk density values of lower soil depths due to the effects of weight of the overlying soil and the corresponding decrease in soil organic matter content. 


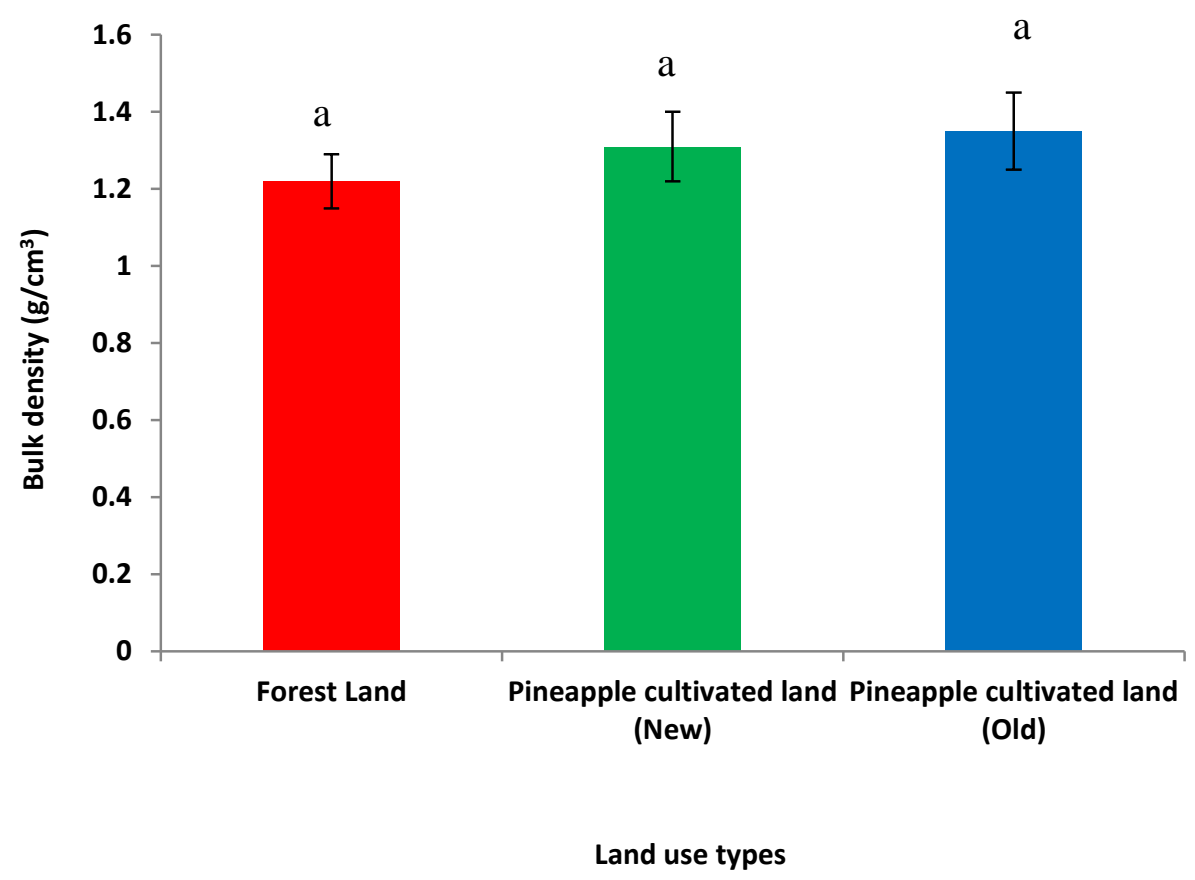

Figure 1. Mean $( \pm \mathrm{SE})$ soil bulk densities of pineapple and forest soils at Matara district

When bulk density is high, root growth, movement of air and water in the soil is restricted (Osakwe andIgwe 2013). However, as stated by Kolay (2000), the bulk density of a productive natural soil generally ranges from 1.1 to $1.5 \mathrm{gcm}^{-3}$. Therefore, the lands investigated under the present study could be considered as productive as the values of bulk density ranged from $1.22 \mathrm{~g} \mathrm{~cm}^{-3}$ (in the forest land) to $1.35 \mathrm{~g} \mathrm{~cm}^{-3}$ (in the old pineapple land)

\section{Soil Texture}

The cultivated soils indicated comparatively higher clay contents and lower sand percentages than those of the adjoining forestland and the values between cultivated lands and forest land were significantly different (Table 1) However, there was no significant difference in clay and sand contents between old and new pineapple lands. The mean silt and clay contents were significantly higher in cultivated lands. The forest lands had the lowest mean silt and clay contents. According to these results, the highest and lowest mean sand contents were observed in the forest and new pineapple soils respectively. The soil texture was loamy sand in all land use types (Table 1). This indicates the homogeneity of soil forming processes and 
the similarity of parent materials. The highest mean clay fraction was recorded in the soils of the cultivated lands and the lowest was observed in the soils of the forest land (4.1\%). The highest clay percentage observed in the soils of the cultivated lands might be due to the degree of weathering and tillage activities (Khresat et al. 2008). The distribution of particle size, in the present study, reveals a decrease in larger particle size and an increase in smaller particle size contents following the conversion of natural forest to other land-use cover. Clay particles are very small particles and they are very slow to settle out by runoff. Therefore, lower content of sand and higher content of clay fractions in the cultivated land may be attributed to lands with runoff and deposited on the topsoil of forestland (Biro et al. 2013). The processes of ploughing, clearing and the levelling of surface horizons of the farming fields may also have attributed to the increased clay content in cultivated lands (Adugna and Abegaz 2016). Furthermore, cultivation promotes physical weathering processes as it shears and pulverizes the soil and changes the moisture and temperature regimes. The absence of protective vegetation cover in the cultivated land also indirectly contributes to the removal of finer particles as it reduces the organic matter that disturbs soil aggregates and accelerates soil loss via erosion (Abbasi et al. 2007). Soils with high clay content have sufficient particle-to-particle contact points to form strong bonds when the soil dries (Eyayu et al. 2009). Cultivated land with the highest clay fraction has the most compacted soils.

Table 1: Mean $( \pm$ SE) percentages of sand, silt and clay of pineapple and forest soils at Matara district

\begin{tabular}{lllll}
\hline Lands type & Sand \% & silt \% & clay \% & Soil texture \\
\hline Forest land & $85.2^{\mathrm{a}} \pm 1.0$ & $10.7^{\mathrm{b}} \pm 0.6$ & $4.1^{\mathrm{b}} \pm 0.4$ & Loamy sand \\
New pineapple cultivated land & $74.8^{\mathrm{b} \pm 1.2}$ & $12.3^{\mathrm{a}} \pm 0.8$ & $12.9^{\mathrm{a}} \pm 0.8$ & Loamy sand \\
Old pineapple cultivated land & $78.1^{\mathrm{b} \pm 1.1}$ & $9.1^{\mathrm{b}} \pm 0.5$ & $12.8^{\mathrm{a}} \pm 0.9$ & Loamy sand \\
\hline
\end{tabular}

Means with the same letters are not significantly different at 5\% level. 


\section{Soil Aggregate Stability}

The mean weight diameter (MWD) is commonly used to express aggregate stability. It determines the size distribution of aggregates and is essentially a measure of macro-aggregate stability as the aggregates that remained on each sieve must be stable to the wetting and sieving processes (Quanchao Zeng, 2018). There was a significant difference in aggregate stability between the forest land and cultivated lands (Table 2). The cultivated soils have considerably lower aggregate stability than that compared to forest land. According to Ayoubi et al. (2011), aggregate stability depends on interaction between primary particles and organic constituents. It varies with soil environmental conditions, and management practices and Caravaca et al. (2003) indicated that cultivated soils have comparatively lower aggregate stability (mean $40 \%$ ) compared to that forest soils (mean 82\%). The results are in agreement with Celik (2005) and Evrendilek et al. (2004), who observed lower aggregate stability in cultivated soil and higher aggregate stability in forest soil.

Table 2: Mean $( \pm \mathrm{SE})$ soil aggregate stability of pineapple and forest soils at Matara district

\section{Land type}

Forest land

New pineapple cultivated land

Old pineapple cultivated land

\section{Mean weight Diameter (mm)}

Means with the same letters are not significantly different at 5\% level.

\section{Soil $\mathrm{pH}$}

Soil $\mathrm{pH}$ showed a significant difference between old pineapple land and forest land. However, no such variations were observed between two cultivated lands and also between new pineapple land and forest land (Fig. 2). Soil reactions for all the soil samples were moderately acidic to slightly acidic (5.7-4.8) which might be 
due to the removal of bases with high rainfall and subsequent rapid erosion and the depletion of basic cations through crop harvesting.

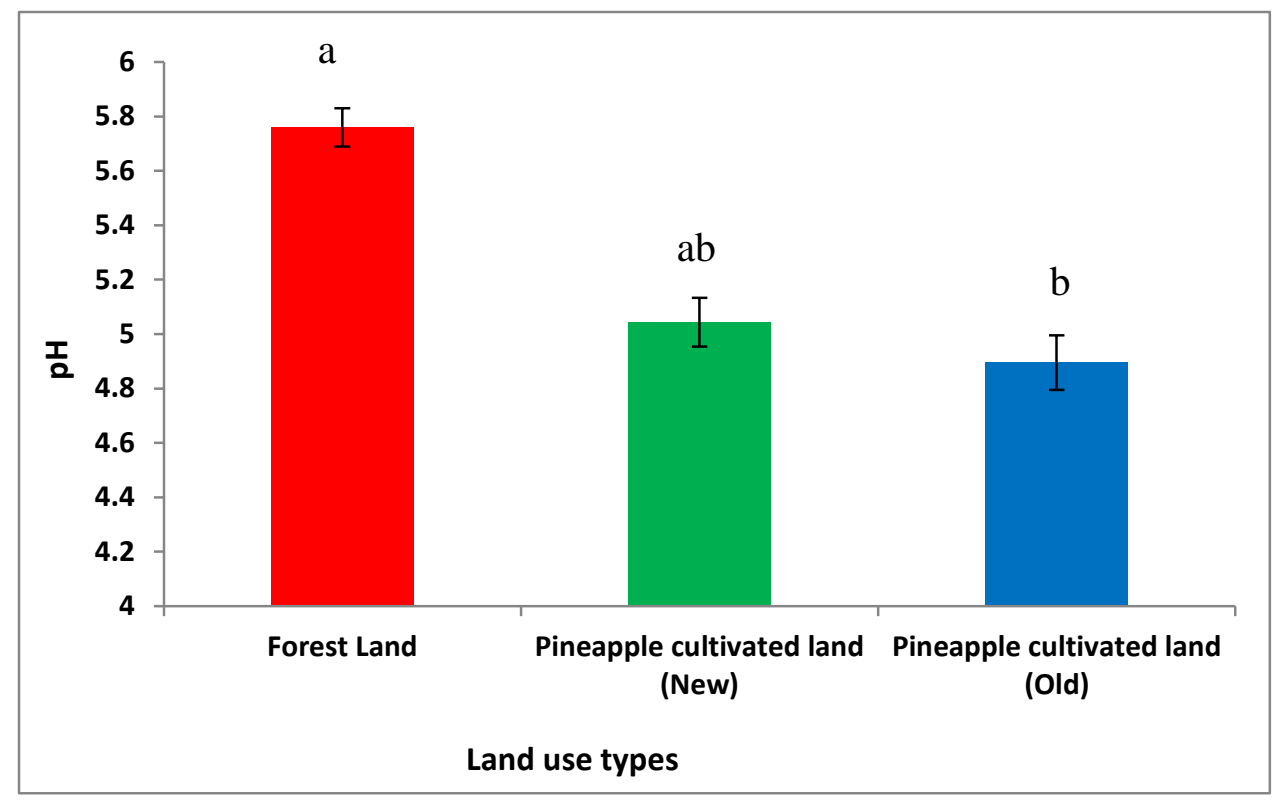

Figure 2. Mean $( \pm \mathrm{SE})$ soil $\mathrm{pH}$ of pineapple and forest soils at Matara district.

The low $\mathrm{pH}$ value in the old pineapple land may be due to continuous cultivation of pineapple for a long period and also plants absorb more basic nutrients such as calcium, potassium and magnesium for their growth with the time (Adugna and Abegaz 2016). Soil acidity affects the process of biological transformations and bioavailability of many plant essential nutrients (Barua and Haque, 2013). Frequent application of urea base nitrogen fertilizers also indirectly contributes to the low soil $\mathrm{pH}$ values. Urea is dissolved in soil water and rapidly convert into ammonia $\left(\mathrm{NH}_{3}\right)$ gaseous form and then to ammonium $\left(\mathrm{NH}_{4}^{+}\right)$when hydrogen ions are plentiful in soils. Through the nitrification process that involved in nitrification bacteria, these ammonium ions converted into nitrate ions $\left(\mathrm{NO}_{3}^{-}\right)$ which release lots of $\mathrm{H}^{+}$ions into soil solution decreasing soil $\mathrm{pH}$. The present results are in agreement with Adugna and Abegaz (2016) and Emiru and Gebrekidan (2013) who observed soils in the cultivated lands with lower $\mathrm{pH}$ than those of the forest and grazing lands. Some researchers reported slightly low $\mathrm{pH}$ for forest soil compared to that of soils under cultivated lands (Biro et al. 2013; Abad et 
al. 2014;) which might be due to preweathered parent materials and leaching of basic cations.

\section{Soil organic matter}

Soil organic matter content shows a strong response to land use change and land degradation thus could be considered as one of the most reliable indicators available for assessing potential productivity in different land use types and management systems (Vågen and Winowiecki 2013). There was a significant difference in soil organic matter content between forest land and pineapple lands (Fig. 3). Forest soil had significantly higher quantity of organic matter which reduced drastically due to the conversion of natural ecosystems into agricultural ecosystems. This might be due to regular addition of litter materials from above- and belowground plant biomass their reduced rate of disturbance. In forest lands, the contribution of below-ground biomass in organic carbon accumulation was more than above-ground. The expanded root system of perennial trees and grasses, lack of tillage, and livestock addition also contributed more inorganic carbon storage. The lowest organic matter content was recorded in old pineapple land (Fig.3). This may be due to reduced organic matter inputs to the soil system, accelerated rate of microbial decomposition, removal of green materials with the harvest, and loss of organic matter by erosion. There are some similar reports on remarkable depletion of the soil organic matter stock after changing forest land to cultivated land (Emiru and Gebrekidan 2013). Obviously, the forest clearing followed by the conversion of forest land into the cultivated land has led to a drop in soil organic matter contents. Cultivated soils generally have low organic matter content compared to native ecosystems, since cultivation increases aeration of the soil, which enhances the decomposition of SOM (Kizilkaya and Dengiz 2010). 


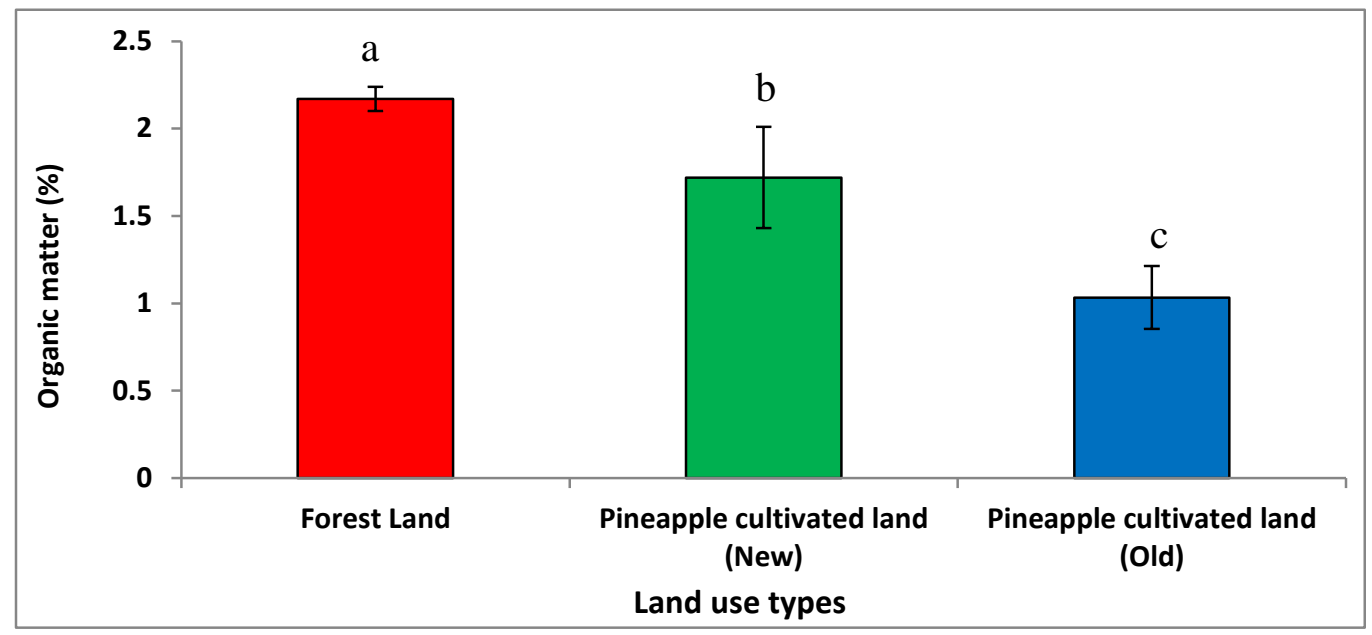

Figure 3: Mean $( \pm$ SE) organic matter $(\%)$ of pineapple and forest soils at Matara district

\section{Total nitrogen}

Higher total nitrogen was observed in forest land than that of new and old pineapple lands (Fig. 4). However, there was no significant difference across the different land use types. Most soil nitrogen is generally bound to organic carbon. Moges et al. (2013) also, identified that total nitrogen does not significantly change with different land use types. However, Khresat et al. (2008) reported a significant difference in total nitrogen content between forest and cultivated lands which might be due to considerable differences in soil organic matter content, intensities of erosion, and continuous cultivation. The relatively higher total nitrogen content in forest land could be attributed to the higher organic matter content resulted from a continuous addition of root and above ground biomass to the soil system. The low total nitrogen content reported in cultivated lands might be attributed to the rapid mineralization of soil organic matter due to cultivation. Low inputs of soil organic matter in such lands have contributed to the low total nitrogen content (Moges et al. 2013). 


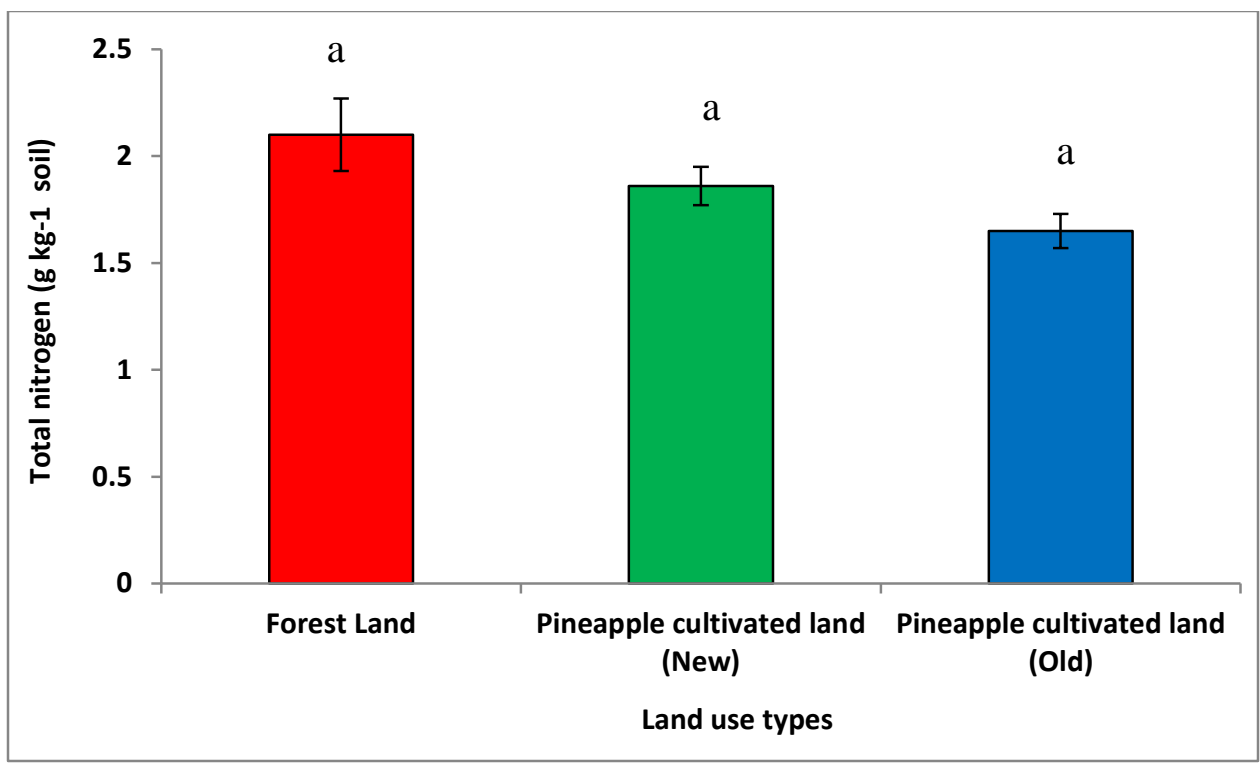

Figure 4: Mean $( \pm \mathrm{SE})$ total $\mathrm{N}\left(\mathrm{g} \mathrm{kg}^{-1}\right)$ of pineapple and forest soils at Matara district

\section{Available phosphorus}

The available phosphorus (P) content was significantly different among land use types (Fig. 5). The highest (17.3 $\mathrm{mg} \mathrm{kg}^{-1}$ ) mean available $\mathrm{P}$ was recorded in the old pineapple land and the lowest was observed in the new pineapple land $(12.4$ $\mathrm{mg} \mathrm{kg}^{-1}$ ). The highest available $\mathrm{P}$ content recorded in the old pineapple land may be due to carryover effects from the continuous application of organic (animal manure, compost, and household waste) and inorganic $\mathrm{P}$ fertilizers (Triple super phosphate, di-ammonium phosphate) for soil fertility improvement. Repeated land preparation practices enhance the weathering processes and release a higher amount of available $\mathrm{P}$ to the soil. The results are in line with Fantaw and Abdu (2011) who observed higher available P content in cultivated soils in Ethiopia. 


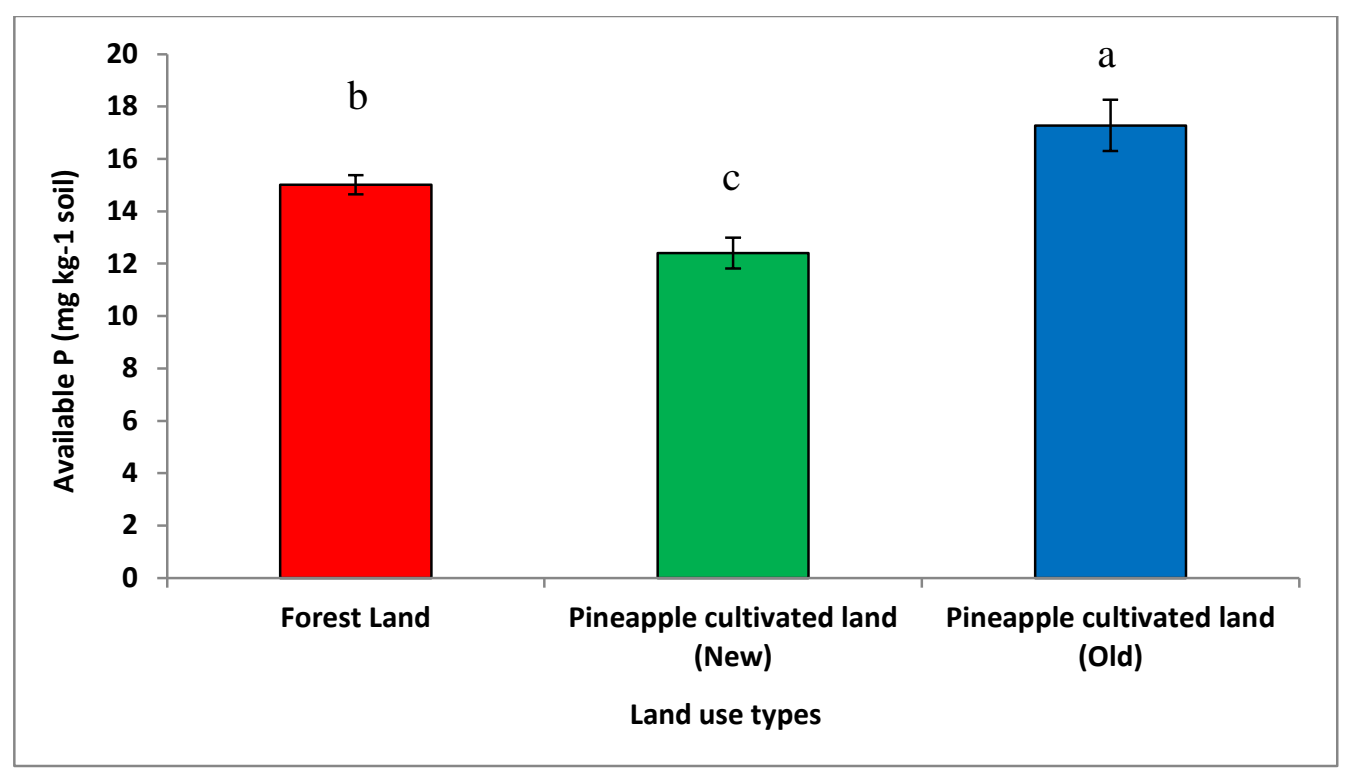

Figure 5: Mean $( \pm \mathrm{SE})$ available $\mathrm{P}\left(\mathrm{mg} \mathrm{kg}^{-1}\right)$ of pineapple and forest soils at Matara district

\section{Exchangeable Potassium}

The highest exchangeable $\mathrm{K}$ content was recorded in old pineapple cultivated land (19.8 $\mathrm{mg} \mathrm{kg}^{-1}$ ) and the lowest (18.3 $\mathrm{mg} \mathrm{kg}$ 1) was observed in the new pineapple cultivated land (Table 3). However, there was no significant difference in the overall concentration of exchangeable $\mathrm{K}$ content with land use types. The highest exchangeable $\mathrm{K}$ content recorded in old pineapple cultivated land may be due to continuous application of organic and inorganic fertilizers for years. The sandy character of the forest soil may therefore account for the relatively lower potassium concentrations in the cultivated lands. Similar to our findings, Moges et al. (2013) observed higher exchangeable $\mathrm{K}$ content in soil under the farmlands compared to the adjacent natural forest. Unlike nitrogen and phosphorus, potassium is not associated to any great extent with organic matter and is most often found in the soil as inorganic forms. 
Table 3: Mean $( \pm \mathrm{SE})$ exchangeable- $\mathrm{K}\left(\mathrm{mg} \mathrm{kg}^{-1}\right)$ of pineapple and forest soils at Matara district

Lands type Mean value (ppm)

Forest land $18.8^{\mathrm{b}} \pm 1.85$

New pineapple cultivated land $\quad 18.3^{\mathrm{b}} \pm 2.13$

Old pineapple cultivated land $\quad 19.8^{\mathrm{b}} \pm 1.92$

Means with the same letters are not significantly different at 5\% level.

changes on soil physicochemical

\section{Conclusions}

The results of this study showed that differences in the selected soil physical and chemical properties on different land use types. Significant differences in soil organic matter, soil $\mathrm{pH}$, aggregate stability, and available $\mathrm{P}$ were observed between forest and cultivated lands. However, the bulk density, total nitrogen, and exchangeable $\mathrm{K}$ contents of forest and cultivated lands were not significantly different ( $p \geq 0.05)$. Based on the results, it is clear that there is a need for greater attention to developing sustainable land use practices in management of these agro-ecosystems.

\section{References}

Abad J R S, Khosravi H, Alamdarlou E H (2014) Assessment the effects of land use properties in Jafarabad of Golestan province, Bull Environ Pharm Life Sci 3: 296-300.

Abbasi M K, Zafar M, Khan S R (2007) Influence of different land-cover types on the changes of selected soil properties in the mountain region of Rawalakot Azad Jammu and Kashmir. Nutr Cycl Agroecosys 78: 97-110.

Adugna A, Abegaz A (2016) Effects of land use changes on the dynamics of selected soil properties in northeast Wellega, Ethiopia. Soil 2:63-70.

Ayoubi S, Khormali F, Sahrawat K L, Rodrigues de Lima A C (2011) Assessing impacts of land use changes on soil quality indicators in a loessial soil in Golestan province, Iran. J Agric Sci Technol 13:727742. 
Barua S K, Haque S M S (2013) Soil characteristics and carbon sequestration potentials of vegetation in degraded hills of Chittagong, Bangladesh. Land Degrad Dev 24: 63-71.

Biro K, Pradhan B, Muchroithner M, Makeschin F (2013) Land use/land cover change analysis and its impact on soil properties in the northern part of Gadarif region, Sudan, Land Degrad . Dev 24: 90102.

Braimoh A K, Vlek P L (2008). Impact of land use on soil resources. In: Land Use and Soil Resources, Springer, Dordrecht.

Bremner D C. Mulvaney J M (1982). Total Nitrogen. In: Page A L, Miller $\mathrm{R} \mathrm{H}$ and Keeney D R (eds.) Methods of soil analysis, Part 2, 2nd edn. (Agronomy monograph no. 09) American Society of Agronomy, and Soil Science Society of America, Madison, Wis. pp 595-624.

Caravaca F, Barea J M, Palenzuela J, Figueroa D, Alguacil M M, Roldan A (2003) Establishment of shrub species in a degraded semiarid site after inoculation with native or allochthonous arbuscular mycorrhizal fungi. Appl Soil Ecol 22: 103111.
Celik I (2005) Land use effects on organic matter and physical properties of soil in a southern Mediterranean highland of Turkey. Soil Till. Res 83:270-277.

Dick W A, Tabatabai M A (1977). An alkaline oxidation method for determination of total phosphorus in soils. Soil Sci Soc Am J 41: 511-514.

Emiru N, Gebrekidan H (2013) Effect of land use changes and soil depth on soil organic matter, total nitrogen and available phosphorus contents of soils in Senbat watershed, western Ethiopia, J Agric Biol Sci 8: 206-212.

Erdal S (2012) Organic carbon organic matter and bulk density relationships in arid-semi arid soils in Southeast Anatolia region. Afr. J. Biotechnol. 11:1373-1377.

Evrendilek F, Celik I, Kilic S (2004) Changes in soil organic carbon and other physical soil properties along adjacent Mediterranean forest, grassland, and cropland ecosystems in Turkey. J Arid Environ 59:743-752.

Eyayu M, Heluf G, Tekaliign M, Mohammed A (2009) Effects of land use change on selected soil properties in the Tera Gedam Catchment and adjacent agro-ecosystems, 
Northwest Ethiopia. Ethiopian J Nat Resour 11: 35-62.

Fantaw Y, Abdu A (2011) Soil property changes following conversion of acacia woodland into grazing and farmlands in the rift valley area of Ethiopia, Land Degrad Dev 22:425-431.

Gee W G and Or D (2002) Particle-Size Analysis. In: Dane J and Topp G C(eds.) Methods of soil analysis, Part 4, American Society of Agronomy, and Soil Science Society of America, Madison, Wis. pp 255293.

Gu Y, Zhang L, Ding S, Qin S (2011) The soil macrofaunal community structure under a long-term fertilization in wheat field. Acta Ecol Sinica 31: 4900-4906.

Helmke P A, Sparks D L (1996) Lithium, sodium, potassium, rubidium, and cesium. In: Sparks D L (eds.) Methods of soil analysis, Part 3. Chemical methods. American Society of Agronomy, and Soil Science Society of America, Madison, Wis. pp 551-574.

Karltun E, Lemenih M, Tolera M (2013) Comparing farmers' perception of soil fertility change with soil properties and crop performance in Beseku, Ethiopia. Land Degrad Dev 24: 228-235.

Keith A M, Boots B, Hazard C, Niechoj R, Arroyo J (2012) Cross-taxa congruence, indicators and environmental gradients in soils under agricultural and extensive land management. Eur J Soil Biol 49: 55-62.

Kemper W D, Chepil W S (1965) Size distribution of aggregates. In: Black C A, Evans D D, White J L, Ensminger L E, Clark F E (eds.) Methods of soil analysis, Part 1. American Society of Agronomy and Soil Science Society of America, Madison, Wis. Pp 499-510.

Khresat S, Al-Bakri J, Al-Tahhan R (2008) Impacts of land use/cover change on soil properties in the Mediterranean region of northwestern Jordan. Land Degrad Dev 19:397-407.

Kizilkaya R, Dengiz 0 (2010) Variation of land use and land cover effects on some soil physico-chemical characteristics and soil enzyme activity. Zemdirbyste 97:1524.

Kolay A K (2000) Basic concepts of soil science, 2nd edn. New Age International Publishers, New Delhi. pp 78-80, 90-91, 102-105, 138. 
Kröpfl A I, Cecchi G A, Villasuso N M, Distel R A (2013) Degradation and recovery processes in Semi-Arid patchy rangelands of northern Patagonia, Argentina. Land Degrad Dev 24: 393-399.

Mapa R B, Somasiri S, Nagarajah S (1999) Soils of the wet zone of Sri Lanka. Soil Sci Soc SL pp 2392.

Moges A, Dagnachew M, Yimer F (2013) Land use effects on soil quality indicators: a case study of Abo-Wonsho Southern Ethiopia. Appl Environ Soil Sci. doi:10.1155/2013/784989

Mulugeta L, Karltun E, Olsson M (2005) Soil organic matter dynamics after deforestation along a farm field chronosequence in southern highlands of Ethiopia. Agr Ecosyst Environ 109: 9-19.

Muñoz-Rojas M, Erickson T, Merritt D, Dixon K (2015) Applying soil science for restoration of post mining degraded landscapes in semi-arid Australia: challenges and opportunities. Geophys. Res. 17: 3967-1.

Nascente A S, Yuncong L, Carlos A C C (2015). Soil aggregation, organic carbon concentration, and soil bulk density as affected by cover crop species in a no- tillage system. Rev Bras de Ciênc Solo, 39: 871-879.

Nelson D W, Sommer L E (1996) Total carbon, organic carbon and organic matter. In: Sparks D L (eds.) Methods of soil analysis, Part 3. Chemical methods. American Society of Agronomy, and Soil Science Society of America, Madison, Wis. pp 961-1010.

Nietupski M, Sowinski P, Sadej W, Kosewska A (2010) Content of organic C and $\mathrm{pH}$ of bog and post-bog soils versus the presence of ground beetles Carabidae in Stary Dwor near Olsztyn. J Elementol 15: 581-591.

Offiong R A, Iwara A I (2012) Quantifying the Stock of Soil Organic Carbon Using Multiple Regression Model in a Fallow Vegetation, Southern Nigeria. Ethiopian J Environ Stud Manag 5: 166-172.

Osakwe U C, Igwe C A (2013) Conversion of forests to arable land and its effect on soil physical properties in Enugu State South Eastern Nigeria. Nigerian J Biotechnol 26, 33-40

Paul K I, Polglase P J, Nyakuengama J G, Khanna P K (2002) Change in soil carbon 
following a forestation. For Ecol Manag 168:241-257.

Punyawardena B V R, Bandara T M J, Munasinghe $\mathrm{M}$ A $\mathrm{K}$, Banda $\mathrm{N}$ J, Pushpakumara S M V (2003) Agroecological Regions of Sri Lanka. Natural Resources Management Center, Department of Agriculture, Peradeniya.

Saha D, Kukal Z P (2015) Soil structural stability and water retention characteristics under different land uses of degraded 5 lower Himalayas of NorthWest India, Land Degrad Dev 26: 263271.

Santorufo L, Van Gestel C A, Rocco A, Maisto G (2012) Soil invertebrates as bioindicators of urban soil quality. Environ Pollut 161: 57-63.

SAS Institute (1988). SAS/STAT user's guide, Release 6.03. SAS Institute, Cary, North Carolina, USA.

Selassie Y G, Anemut F, Addisu S (2015) The effects of land use types, management practices and slope classes on selected soil physico-chemical properties in Zikre watershed, North-Western Ethiopia. Environ Syst Res 4:3.
Ubuoh E A, Akhionbare W N, Oweremadu E, Onifade O A (2013) Characterization of Soil Quality in Erosion Prone Environment of Ukpor, Nnewi-South L.G.A. of Anambra State, Nigeria. Int J Adv Appl Sci 2:1 8.

Vågen T G, Winowiecki L A (2013) Mapping of soil organic carbon stocks for spatially explicit assessments of climate change mitigation potential. Environ Res Lett 8:1-3.

Wang G Q, Jiang H, Xu ZX, Wang L J, Yue W F (2012) Evaluating the effect of land use changes on soil erosion and sediment yield using a grid-based distributed modelling approach. Hydrol Process 26:3579-3592.

Wanniarachchi S D, Shyamalee H A P A (2005) Monitoring soil quality in low country wet zone agricultural lands: identifying soil quality indicators responsive to land management, Proceedings of the 61st Annual Sessions of the Sri Lanka Association for the Advancement of Science, Colombo, Sri Lanka. pp. 15-16.

Wang W J, He H S, Zu Y G (2010) Addition of HPMA affects seed germination, plant growth and properties of heavy salinealkali soil in northeastern China: 
comparison with other agents and Krachan National Park, Thailand. Soil determination of the mechanism. Plant Water Res 7:10-17.

Soil: 339, 177-191.

Wijitkosum S (2012a) Evaluation of Wijitkosum S (2016) The impact of land impacts of spatial land use changes on soil loss using remote sensing and GIS in Huay Sai Royal Development Center. Thail J Environ Res Dev 6:487-493.

Wijitkosum S (2012b) Impacts of land use changes on soil erosion in $\mathrm{Pa}$ Deng subdistrict, adjacent area of Kaeng use and spatial changes on desertification risk in degraded areas in Thailand. Sustainable Environ Res 26:84-92.

Quanchao Zeng, Frédéric Darboux, Cheng Man, Zhaolong Zhu, Shaoshan An (2017) Soil aggregate stability under different rain conditions for three vegetation types on the Loess Plateau (China). Catena, Elsevier, 167:276-283. 